\title{
The Influence of Macro Economic Factors on Mortgage Market Growth in Kenya
}

\author{
Ariemba Jared Mogaka ${ }^{1, ~ *, ~ K i w e u ~ J o s e p h a t ~ M b o y a ~}{ }^{2}$, Riro George Kamau ${ }^{3}$ \\ ${ }^{1}$ School of Business and Economics, South Eastern Kenya University, Kitui, Kenya \\ ${ }^{2}$ School of Management and Commerce, Strathmore University, Nairobi, Kenya \\ ${ }^{3}$ School of Business Management and Economics, Dedan Kimathi University of Technology, Nyeri, Kenya
}

Email address:

jared.ariemba@gmail.com (A. J. Mogaka)

\section{To cite this article:}

Ariemba Jared Mogaka, Kiweu Josephat Mboya, Riro George Kamau. The Influence of Macro Economic Factors on Mortgage Market Growth in Kenya. Journal of Finance and Accounting. Vol. 3, No. 4, 2015, pp. 77-85. doi: 10.11648/j.jfa.20150304.13

\begin{abstract}
This study examines the influence of macro-economic variables on the growth of the mortgage market in Kenya. Panel data is collected for a 30 year period, from 1984 to 2013 on the outstanding Real Estate Loan Portfolio as the dependent variable and the macro-economic variables of Average Yearly Inflation Rate, Average Yearly GDP growth Rate, Average Yearly Exchange Rate, Percentage Informal Sector Employment, Treasury bill rate and National Savings Rate as the predictor variables. Regression Analysis was used and the study found no evidence of significant influence of inflation, average GDP growth rate, Treasury bill rate and national savings rate on total real estate loan portfolio. However, the study finds evidence of relationship between informal sector employment, the per capita income and exchange rate. However, the model showed that $81 \%$ of the variation in the dependent variable could be explained by the predictor variables.
\end{abstract}

Keywords: Real Estate, Mortgage Market, Macro-Economic Factors

\section{Introduction}

According to the World Bank (2012) world development indicators report, a macro-economic factor is one that is pertinent to a broad economy at the regional or national level and affects a large population rather than a few select individuals. Examples of such factors include economic output, unemployment, inflation, savings and investment among others. The Kenya National Bureau of Statistics normally provides data on various economic development indicators, like inflation, informal sector employment, national savings rate, GDP growth rate, GDP per capita among others. This study seeks to unlock the relationship between such macro-economic variables and the development of the mortgage market.

The mortgage market is the market for financing real estate assets (Femi, 2013).It has been observed by Levine (1997) that provision of housing cannot be successful if a nation does not have a well developed mortgage market. Lwali, (2008) argues that in Kenya, the institutions involved in the provision of mortgages include commercial banks, specialized mortgage firms, saving and loans firms, insurance companies, government parastatals, pension funds, trusts and other real investment.

Central Bank of Kenya (2013) argues that commercial banks dominate mortgage lending in Kenya, with 43 banks and one Mortgage Finance Company, 36 of them having mortgage portfolios of differing sizes. Central Bank of Kenya authorizes two types of lenders, the ordinary banks and the mortgage companies. Similar regulations with regards to mortgage financing apply to the two types of lenders.

A number of indicators have been used to measure the growth of the mortgage market. The Central Bank of Kenya has been measuring the growth of Kenya's mortgage market in terms of total mortgage lending, number of mortgage accounts and the ratio of mortgage debt to GDP. This is captured in the CBK (2011), CBK (2012) and CBK (2013) surveys among others. Walley et al., (2013), Femi (2013), Warnock and Warnock (2008) among others have also measured the growth of the mortgage market in terms of the ratio of outstanding residential mortgage debt to GDP, the total mortgage lending and the number of mortgage accounts. 
A Central Bank of Kenya (2011) survey showed that the potential stood at KES 800 billion, while the actual volume of mortgage loans disbursed stood at KES 61.4 billion. This showed a market performing at barely $7.6 \%$ of its potential, or can be said to be showing a slack in development of $92.4 \%$. This is reflected on the low ratio of outstanding mortgage debt to GDP of a partly $2.52 \%$, while in many developed economies, it ranges over $50 \%$ according to Central Bank of Kenya (2013) and Beck et al., (2011).

A lot of studies on the influence of economic variables on the mortgage market have focused on inflation and exchange rate stability (Boamah, 2009; Boleat, 2008; Starr, 1975, Rosa, 1976; Bryx, 2006 and Fisher, 1933). These studies have largely been cross-sectional, cutting across different countries. This is a time series study focusing on Kenya's mortgage market for a period of 10 years. This study also seeks to expand the list of macro-economic variables to from not only inflation rate and exchange rate but to also include economic growth rate, informal sector employment and national savings rate.

The remainder of this paper is organized as follows: Section three presents a review of related literature and the research hypotheses. The research method adopted is outlined in section four. Section five presents the results followed by a summary, discussions and conclusions in the final section.

\section{Review of Literature and Hypothesis}

\subsection{Inflation and the Mortgage Market}

Boamah (2009) argues that a macro-economic environment of low inflation is an essential ingredient of a successful mortgage market as it will lead to low and stable interest rates. High inflation leads to high interest rates as lenders seek to compensate loss of purchasing power of their money. Fluctuating interest rates will lead to lenders lending on variable rates. Starr (1975) proposes lowering of mortgage interest rates to increase the availability of housing to moderate and low-income borrowers. Rosa (1978) examines the relationship between housing demand and interest rate on housing finance and found it to be highly elastic.

Bryx (2006) argues that periods of low inflation encourage the development of the real estate market, as interest rates on loans decrease. On the other hand, in case of high inflation we may expect increased property prices, as they often constitute an investment protecting capital from losing value. Also, a lower frequency and severity of economic downturns make household income more stable and may contribute to a willingness to assume higher debt burdens and increased attractiveness of flexible mortgage rate (Akinwunmi, 2008).

Chiquier et al., (2004) and Jaffe and Renaud, (1996) identify interest rate risk as a major risk facing the development of mortgage markets. If lenders make longterm fixed rate mortgages from short-term deposits, the lenders are exposed to interest rate risk. Lenders may seek to control this by using adjustable rate mortgages which transfers the risk to the borrowers. As a result, borrowers are exposed to interest rate risk which may lead to unaffordable interest payments for the mortgage loans in times of economic crisis. Butler et al., (2009) posits that if inflation is volatile, lenders will incur high interest rate risk if they lend at a fixed rate. Lenders may therefore pass the risk to the borrowers through high interest. High interest risk will either push the lenders out of business or borrowers will be unable to pay.

Warnock and Warnock, (2008) and Boleat, (2003) also argue that deeper mortgage markets are associated with a stable macro-economic climate. Boleat (2003) argues that long term loans are not possible when inflation and interest rates are high and volatile and there must also be general economic stability. He further argues that the ideal state of borrowing would be at an interest rate of three to four percent above the cost of funds, but in most emerging markets the actual spread is five to eight percent and in developed markets it is under two percent. An effective regulatory system decreases that spread and thus allows for expansion in the mortgage market

IDB (2005) argues that interest rate instability is one of the factors that could explain the small size of the mortgage market in Latin America. The study asserts that the typical annual variation in the real interest rate for borrowing is 5.3 percentage points in Latin American countries, whereas in developed countries it is 1.6 percentage points. In countries like Argentina, Brazil, Ecuador, and Peru, the typical real interest rate variation in the previous decade was between 17 and 18 percentage points, and only in Belize and Panama was it similar to or less than in developed countries.

Green and Wachter (2007) emphasize on the availability and cost of mortgages as crucial determinants in the functioning housing markets across countries. They cited the decline in nominal prime interest rates from an average of 15 percent in 1980 to 4.4 percent in 2004 across several countries. The major outcome of this was improved access to mortgages, increase in demand for housing, and increase in house prices across most of the industrialized countries in the world. It was clear from their study that fall in interest rates induces higher demand for mortgages

Huybens and Smith (1998) argue that an increase in the rate of inflation could have at first negative consequences on financial sector performance through credit market frictions which entail the rationing of credit leading to reduction in intermediary activity as well as capital formation. Arcelus and Meltzer (1973) state that when market rates of interest rise, and when expectations of higher inflation in the long run keep interest rates at the higher levels, it would not reduce housing demand permanently because after a time lag, wages and house prices would adjust to the higher anticipated inflation.

Using regression analysis, Walley et al., (2013) found that inflation is negatively and significantly associated with mortgage market development. Inflation volatility was 
negatively and significantly associated with Mortgage Depth, while positively and significantly with Housing Loan Penetration, which may indicate the use of housing loans (and thus real estate more generally) as a hedge against inflation, where available. In a study covering 61 countries, Warnock and Warnock, (2008) found that deeper mortgage markets were associated with a stable macroeconomic climate of low and stable inflation.

In a study of the demand for mortgages under macrovolatility in Argentine, IDB (2011) employed both macro data and survey information. The study found that demand for mortgages plays an important role in mortgage market development. However, recurring macro volatility and violation of financial property rights increased demand for real estate as an investment, which in turn raised house prices and made it more difficult for consumer households to meet minimum income requirements for obtaining a mortgage.

The above literature forms the basis of hypothesis No 1 as shown at the end of this literature review.

\subsection{Exchange Rate and the Mortgage Market}

Boamah (2009) also argues that a stable currency is an essential ingredient of a successful mortgage market. This is because unstable exchange rates will not attract long-term foreign capital. Lwali (2008) noted that the demand for housing in Sub-Saharan Africa (SSA) has surpassed the supply. In an effort to meet this demand a few International Housing Finance Institutions (IHFI) have come into play. These include Shelter Afrique, overseas private investment corporation, East African Development Bank (EADB) and PTA bank among others.

Apak and Guney (2011) identify currency risk as one of the major risks in the establishment of a mortgage market in developing countries. Due to capital outflows. They give an example of the global financial crisis when lenders of hedge funds in the U.S. demanded their funds back due to liquidity problems in the financial markets. The hedge funds therefore sold many of their liquid financial assets in the developing countries to respond to the demands of their lenders leading to currency outflows that created a problem in the affected financial markets.

Boamah (2011) used regression analysis on mortgage originations in Ghana with inflation, interest, and exchange rates to determine their impacts on mortgage market activities. He found out that the only significant factor influencing mortgage origination in the country is the exchange rate. He suggested that this exists because mortgages in Ghana were denominated in foreign currencies (United States dollar) and that mortgagees focused on Ghanaian residents abroad or Ghanaians with foreign currency denominated income. He also noted that resident Ghanaians have been priced out of the mortgage market by high exchange rate levels and the denomination of mortgages in foreign currencies. This literature leads to hypothesis No 2 as stated at the end of this literature review.

\subsection{Economic Growth Rate and the Mortgage Market}

Hubbard and Mayer (2009) argue that periods of economic growth have some important features that influence the mortgage market. Economic growth creates a legitimate expectation among consumers and investors of continued economic development. This encourages consumer spending and business investment which in turn increases the demand on the money supply moving through the economy. Higher demand for money puts upward pressure on interest rates throughout the economy. On the other hand, economic decline influences the mortgage market because consumers and investors spend less money hence reducing the demand for money. With less competition for money, interest rates are pushed downward and for prospective home buyers, lower interest rates during periods of low economic growth can help decrease the long-term cost of home ownership.

Hofmann (2001) found that in 16 industrialized countries, the annual rate of change in real credit is closely related to that of real GDP. Suljoti and Hashorva (2011) studied the impact of mortgage loans on the residential prices, GDP per capita and interest rate in the demand for mortgage loans. GDP per capita and residential prices are positively correlated with the demand of housing loans from individuals. This forms the basis of hypothesis No 3 below which seeks to examine the influence of economic growth on the growth of the mortgage market.

\subsection{Informal Sector Employment and the Mortgage Market}

Mortgage lenders are also concerned with the ability to pay by a prospective borrower. One should have not only sufficient but also consistent income. According to Chiquier \& Lea (2009), mortgage lenders determine a borrower's ability to repay by comparing monthly payments to income and by assessing the presence of liquid reserves, investments and savings. Gelfand (1970) suggested that lenders will prefer borrowers with stable incomes

This is the very first criterion and others like collateral become irrelevant if this is not met. It is argued that lenders cannot provide mortgages only to have to foreclose on them soon afterwards. This restricts mortgage finance to households with adequate levels of income or savings and this, by definition, excludes the poor according to De Soto (2000). The most common measure for the ability to repay is the debt-to-income ratio. The higher the ratio, the greater stresses will the debt payments place on households. Lenders further assess borrowers' willingness to pay by collecting information on his historical record of payments of other debts.

After using a multi-clustered stratified sample data of households residing in informal settlements in Jakarta, Indonesia, Saleh (1999) found that mortgage loans were inaccessible to majority of households employed in the informal sector due to the nature of their incomes and the strict requirements of loan collateral by the formal housing finance sector.

Using ratio analysis, Taylor and Jureidini (1994) found 
that housing repayment requirements for women borrowers in Australia were consistently higher by more than ten percent than for men. They hypothesized that this could be due to the secondary status assigned to women's income and the uncertainty of continuation of women in work owing to domestic reasons.

Quigley and Raphael (2004) hold that housing choices are more likely to be based on assessment of permanent incomes made by borrowers. In a study based on a sample analysis of 13,487 home loan accounts with leading housing finance companies and public sector banks, Bandyopadhyay and Saha (2009) found that more than 90 percent of borrowers belonged to the category of 'employed', while the remaining borrowers were either self-employed, unemployed or pensioners. It indicates the high value that lenders place on regularity of income in sanctioning loans. Income was also found to be an important consideration as lenders were found to be lending more to younger borrowers for the longer residual working life they implied.

Gandelman and Gandelman (2004) estimate that the probability of access to mortgage lending rises 4 percent for every 10 percent increase in household income, based on household surveys for Uruguay. IDB (2005) however argues that home ownership among low income households is very high in Latin America and such households have very good quality housing. They may therefore not be able to afford a mortgage but through self build, they are able to have homes over time without borrowing from any financial institution. Therefore, a lender may perceive a high risk of nonpayment, even if the borrower has the ability to pay the asymmetric character of information, resulting from the fact that the borrower cannot prove that his or her sources of income are sufficient. Also, the instability of the borrower's income raises the risk of default on installments, even when the borrower might have the ability to pay while the loan is in effect.

Demir et al., (2003) argues that employment is a factor influencing demand for housing loans. If the unemployment level in an economy is low, the potential house buyers' ability to engage with housing finance market increase. Hardt (2000) asserts that lack of job security and existence of informal employment determines the ability to access the housing loans.

In a study based in Kampala, Uganda, Mugambe, (2009), found that financiers will seek for proof of regular source of income preferably in permanent employment and will lend to those who can afford monthly repayments not exceeding $35 \%$ of the borrower's monthly income and they can only finance up to $70 \%$ for urban areas housing and up to $60 \%$ for housing in other areas. He argues that the low levels of income and presence of a large informal sector which often make it difficult to estimate the potential borrower's income constrain the development of the mortgage market.

Mostafa (2012) found that it is difficult to guarantee a mortgage for long term payment if the employment contract is for a fixed duration of time. He found a mismatch between mortgage tenor and the tenor of employment in the
Egyptian mortgage market. Bhide, Gupta, Buragohain, Sethi, Kumar S. and Bathla (2009) cite uncertainty of rural incomes as the major deterrent for formal housing finance to reach out to rural demand for housing finance. This literature leads to hypothesis No 4 as stated at the end of this literature review.

\subsection{National Savings Rate and the Mortgage Market}

It has been observed that one of the main requirements of the mortgage market is the availability of funds in form of accumulated savings. When the level of savings in an economy is high, the funds available to the mortgage market are high. Boleat (1985) posits that the mortgage market depends on the transfer of funds from savers to borrowers who are in need of funds to purchase a house. The mortgage lenders are in business of financial intermediation and will therefore rely on accumulated savings in an economy. Okpala et al, (2006) argue that the accumulated savings in developing countries is not high. He further argues that insufficient capital accumulation affects the whole economy in general and the mortgage market in particular.

Thompson (1947) attributes the increase in the supply of funds with mortgage lenders to the expansion of deposits and savings.Rosa (1978) used regression analysis to determine the influence of savings rate on housing demand. The study found housing demand to be highly elastic. Mehta and Mehta (1991) examined the extent of financial deepening in India and whether it has improved the distribution of mortgage credit across various income groups in urban India. Their basic argument was that although households are the net savers in the economy, they do not benefit much from the allocation of these savings as banks will mostly lend to the industrial sector and not much to the housing sector. They also stated that if the process of financial inclusion is supplemented by improved access to housing finance, it would.

Okpala et al, (2006) however notes of the capital trends dues to globalization as from the 1980s that have enabled capital to move freely around the world. He also notes that while such foreign capital is important in ensuring the mortgage market of the recipient country is well capitalised, it is also a threat to stability in such countries due to sudden inflows and outflows.

This literature forms the basis of hypothesis No 5 shown below that seeks to determine the relationship between national savings rate and mortgage market growth.

\section{Hypothesis}

Based on the above literature, this paper tests the following hypothesis:

1. $\mathrm{H}_{0}=$ There is no significant relationship between Inflation and Outstanding Residential Mortgage Market Debt.

2. $\mathrm{H}_{0}=$ There is no significant relationship between Exchange Rate and Mortgage Market Growth 
3. $\mathrm{H}_{0}=$ There is no significant relationship between Economic Growth Rate and Mortgage Market Growth

4. $\mathrm{H}_{0}=$ There is no significant relationship between Informal Sector Employment and Mortgage Market Growth

5. $\mathrm{H}_{0}=$ There is no significant relationship between National Savings Rate and Outstanding Residential Mortgage Market Debt.

\section{Methodology}

The methodology adopted is the multiple regression analysis time series secondary data from 1984 to 2014, which were obtained from various sources, majorly the various publications of the Central Bank of Kenya and the Kenya National Bureau of Statistics. The data collected included the Average GDP growth rate per year, Average Yearly Inflation, Average Yearly Exchange Rate, the average Annual GDP growth rate perand Informal Sector Employment. Data was also collected from Central Bank of Kenya on the outstanding portfolio of real estate financing per year which was used as a proxy for the development of the mortgage market.

The data was subjected to a normality test before correlation and regression analysis because correlation and regression analysis are based on the assumption that the data is normally distributed. If the data is not normal, then the results of correlation and regression will be misleading. The Shapiro-Wilk test is most appropriate for small sample sizes of less than 50 observations. For this reason, the Shapiro-Wicks test was used in this study to assess normality. If the significance value of the Shapiro-Wilk test is greater than 0.05 , the data is normal. If it is below 0.05 , the data significantly deviate from a normal distribution (Shapiro and Wilks, 1965).

Correlation analysis was carried out to determine any association between the various independent variables and the dependent variable and hence the appropriateness of the variables to be included in the model. This is because if the variables are not related, then they are totally independent hence regression analysis is not necessary. Karl Pearson Moment correlation was used in conducting the correlation analysis because the data collected was parametric data. The Pearson Moment Correlation ranks between 0 to 1 with 0 denoting no relatedness and 1 denoting a perfect relationship. A score of less than 0.3 denotes a weak association, between 0.3 and 0.7 denotes medium correlation and above 0.7 means the variables are strongly correlated.

It was necessary to test for multicollinearity before the regression analysis. Coakes, Steed \& Price (2008) argue that when the independent variables exhibit strong multicollinearity, then the regression model is deemed unreliable leading to problems when doing interpretation. In situations where the predictors are so similar, then it becomes difficult to know which one is actually causing the effect and one can easily conclude that they measure the same thing. According to Belsley (1991), a condition index greater than 15 indicates a problem of multicollinearity.Condition indices larger than 100 indicate near dependencies that will make the regression coefficients unstable.

Stepwise regression analysis was then used on the model variables. Stepwise regression was selected because the test of multicollinearity indicated that multicollinearity was exhibited by some of the variables. Stepwise regression is appropriate in this case as variables are added to the regression equation one at a time, using the statistical criterion of maximizing the $\mathrm{R}^{2}$ of the included variables. After each variable is entered, each of the included variables is tested to see if the model would be better off it were excluded. The process of adding more variables stops when all of the available variables have been included or when it is not possible to make a statistically significant improvement in $\mathrm{R}^{2}$ using any of the variables not yet included. Since variables will not be added to the regression equation unless they make a statistically significant addition to the analysis, all of the independent variable selected for inclusion will have a statistically significant relationship to the dependent variable.

\subsection{Model Specification}

According to Wichura (2006), the general regression equation when dealing with more than one independent variable is as follows:

$$
Y=\beta+\beta_{1} X_{1}+\beta_{2} X_{2}+\beta_{3} X_{3 \ldots}
$$

For the purpose of this study, the above regression model is modified as follows and used for the analysis:

$$
\mathrm{Y}=\mathrm{A}+\mathrm{B}_{1} \mathrm{X}_{1}+\mathrm{B}_{2} \mathrm{X}_{2}+\mathrm{B}_{3} \mathrm{X}_{3}+\mathrm{B}_{4} \mathrm{X}_{4}+\mathrm{B}_{5} \mathrm{X}_{5}+\mathrm{B}_{6} \mathrm{X}_{6}+\mathrm{e}
$$

Whereby:

$\mathrm{Y}=$ Outstanding Residential Mortgage Debt

$\mathrm{A}=$ Autonomous variable.

$\mathrm{X}_{1}=$ Average Inflation Rate.

$\mathrm{X}_{2}=$ Average GDP growth Rate

$\mathrm{X}_{3}=$ Average Yearly Exchange Rate

$\mathrm{X}_{4}=$ Informal Sector Employment

$\mathrm{X}_{5}=$ National Savings Rate

$\mathrm{e}=$ Stochastic variables.

$\mathrm{B}_{1}=$ Coefficient of X1.

$\mathrm{B}_{2}=$ Coefficient of $\mathrm{X} 2$.

$\mathrm{B}_{3}=$ Coefficient of X3.

$\mathrm{B}_{4}=$ Coefficient of $\mathrm{X} 4$.

$\mathrm{B}_{5}=$ Coefficient of X5.

The outstanding residential mortgage debt indicates the total volume of mortgage loans every year, the average inflation is the arithmetic mean for of the month by month inflation normally reported by the Kenya National Bureau of Statistics for each of the twelve months forming one year while the average exchange rate is the exchange rate of the dollar to the shilling as obtained from the Central Bank of Kenya data for various years. The GDP growth rate is the 
proxy for economic growth and is the arithmetic average growth for twelve months as reported by the Kenya National Bureau of Statistics. Informal Sector Employment is the proportion of the population that as reported by the Kenya National Bureau of Statistics every year is working in the informal sector while the national savings rate is the percentage of national savings to the GDP also as reported by the Kenya National Bureau of Statistics in the various publications.

\subsection{The Data}

Data was collected on the total lending by the banking sector for real estate for the period under study from the annual Central Bank of Kenya bank supervision reports. For the period prior to the year 2000, the data was obtained from the statistical bulletins published by the Kenya National Bureau of Statistics. From the various statistical bulletins of the Kenya National Bureau of Statistics, data was collected on informal sector employment, formal sector employment, inflation, GDP per capita, exchange rate and national savings rate. Data was also obtained from the Central Bank of Kenya publications on the 91 day Treasury bill rate.

\section{Findings}

\subsection{Shapiro-Wilk Test of Normality}

Below shows the Shapiro-Wilk test of correlation for the independent variable total mortgage loans and the independent variables of inflation, GDP growth rate, informal sector employment, national savings rate, GDP per capita and exchange rate.
Table 1. Tests of Normality for macroeconomic variables.

\begin{tabular}{llll}
\hline & Shapiro-Wilk & \\
\cline { 2 - 4 } & Statistic & df & Sig. \\
\hline Total Mortgage Loans & .583 & 30 & .093 \\
Average Inflation & .823 & 30 & .805 \\
Average GDP growth rate & .962 & 30 & .354 \\
Informal Sector Employment & .822 & 30 & .078 \\
Formal Sector Employment & .842 & 30 & .064 \\
National Savings Rate & .937 & 30 & .075 \\
Treasury Bill Rate 91day & .919 & 30 & .095 \\
GDP per Capita \$ & .853 & 30 & .211 \\
Average Exchange Rate & .859 & 30 & .071 \\
\hline
\end{tabular}

As can be observed from the table above, the significance levels of all the data sets are more than 0.05 and therefore the data is normally distributed.

\subsection{Correlation Test}

Each of the independent variables was be analyzed with the dependent variable separately, any relationship observed and a correlation matrix derived. Pearson moment correlation was used to test any association between mortgage loans and inflation, GDP growth rate, GDP per capita, informal sector employment, exchange rate and national savings rate. It was also necessary to test the association between mortgage loans and equity market capitalization to GDP, bond market turnover, insurance assets, pension assets and ratio of private credit to GDP.

The table below shows the correlation matrix for the various economic variables and the total mortgage loans

Table 2. Pearson Moment Correlation for macroeconomic variables.

\begin{tabular}{|c|c|c|c|c|c|c|c|c|c|}
\hline & $\begin{array}{l}\text { Mortgage } \\
\text { Loans }\end{array}$ & Inflation & $\begin{array}{l}\text { GDP } \\
\text { growth } \\
\text { rate } \\
\end{array}$ & $\begin{array}{l}\text { Informal } \\
\text { Sector } \\
\text { Employment } \\
\end{array}$ & $\begin{array}{l}\text { Formal } \\
\text { sector } \\
\text { employment }\end{array}$ & $\begin{array}{l}\text { National } \\
\text { Savings } \\
\text { Rate } \\
\end{array}$ & $\begin{array}{l}\text { Treasury } \\
\text { Bill Rate } \\
\text { 91day } \\
\end{array}$ & $\begin{array}{l}\text { GDP per } \\
\text { Capita } \$\end{array}$ & $\begin{array}{l}\text { Exchange } \\
\text { Rate }\end{array}$ \\
\hline Mortgage Loans & 1 & -.211 & .236 & .512 & -.322 & -.620 & -.247 & .839 & .566 \\
\hline Inflation & -.211 & 1 & -.446 & -.151 & -.237 & .379 & .518 & -.254 & -.148 \\
\hline GDP growth rate & .036 & -.446 & 1 & -.035 & .641 & -.029 & -.381 & .335 & -.040 \\
\hline $\begin{array}{l}\text { Formal Sector } \\
\text { Employment }\end{array}$ & -.322 & -.237 & .641 & -.723 & 1 & .428 & .201 & .701 & .209 \\
\hline National Savings Rate & -.620 & .379 & -.029 & -.729 & .428 & 1 & .400 & -.720 & -.755 \\
\hline Treasury Bill Rate & -.247 & .518 & -.38 & -.222 & .201 & .400 & 1 & -.449 & -.191 \\
\hline GDP per Capita $\$$ & .839 & -.254 & .335 & .656 & .701 & -.720 & -.449 & 1 & .626 \\
\hline
\end{tabular}

As shown in the table above, there is weak a weak correlation between inflation, GDP growth rate and treasury bills rate and mortgage loans. There is medium correlation between informal sector employment, formal sector employment, national savings rate and exchange rate and mortgage loans. There is however a strong correlation between GDP per capita and mortgage loans. The GDP per capita therefore seems to be having the greatest association with mortgage loans followed by exchange rate and informal sector employment in that order. National savings rate has a negative correlation with mortgage loans. 


\subsection{Multicollinearity Test}

The table below indicates the collinearity diagnostics for the macroeconomic variables inflation, GDP growth rate, informal sector employment, national savings rate, 91 day Treasury bill rate, GDP per capita and exchange rate.

Table 3. Collinearity Diagnostics.

\begin{tabular}{|c|c|c|c|c|c|c|c|c|c|c|c|}
\hline \multirow[b]{2}{*}{ Dimension } & \multirow[b]{2}{*}{ Eigenvalue } & \multirow[b]{2}{*}{$\begin{array}{l}\text { Condition } \\
\text { Index }\end{array}$} & \multicolumn{9}{|c|}{ Variance Proportions } \\
\hline & & & $\begin{array}{l}\text { (Consta } \\
\text { nt) }\end{array}$ & $\begin{array}{l}\text { Average } \\
\text { Inflation }\end{array}$ & $\begin{array}{l}\text { Average } \\
\text { GDP } \\
\text { growth } \\
\text { rate }\end{array}$ & $\begin{array}{l}\text { Informal } \\
\text { Sector } \\
\text { Employment }\end{array}$ & $\begin{array}{l}\text { Formal } \\
\text { Sector } \\
\text { Employm } \\
\text { ent }\end{array}$ & $\begin{array}{l}\text { National } \\
\text { Savings } \\
\text { Rate }\end{array}$ & $\begin{array}{l}\text { Treasury } \\
\text { Bill Rate } \\
\text { 91day }\end{array}$ & $\begin{array}{l}\text { GDP per } \\
\text { Capita \$ }\end{array}$ & $\begin{array}{l}\text { Average } \\
\text { Exchange } \\
\text { Rate }\end{array}$ \\
\hline 1 & 6.650 & 1.000 & .00 & .00 & .00 & .00 & .00 & .00 & .00 & .00 & .00 \\
\hline 2 & .696 & 3.091 & .00 & .07 & .02 & .00 & .00 & .01 & .04 & .01 & .00 \\
\hline 3 & .366 & 4.264 & .00 & .04 & .16 & .00 & .00 & .02 & .00 & .00 & .00 \\
\hline 4 & .246 & 5.392 & .00 & .49 & .19 & .00 & .00 & .03 & .00 & .42 & .00 \\
\hline 5 & .149 & 6.687 & .00 & .55 & .01 & .00 & .02 & .00 & .48 & .01 & .00 \\
\hline 6 & .081 & 9.044 & .02 & .12 & .32 & .00 & .14 & .17 & .39 & .02 & .00 \\
\hline 7 & .044 & 12.292 & .02 & .13 & .40 & .01 & .47 & .00 & .03 & .51 & .03 \\
\hline 8 & .011 & 24.624 & .94 & .06 & .02 & .03 & .19 & .62 & .03 & .31 & .00 \\
\hline 9 & .003 & 44.907 & .02 & .02 & .06 & .96 & .61 & .18 & .02 & .14 & .97 \\
\hline
\end{tabular}

Therefore, as can be observed from the table above two of the independent variables, GDP per capita and exchange rate exhibited multicollinearity. As a result of the multicollinearity, stepwise regression was used in the analysis of the data.

\subsection{Stepwise Regression}

The second objective of this study is to establish the influence of the macroeconomic factors of inflation, exchange rate, GDP growth rate, GDP per capita, informal sector employment, treasury bills rate and national savings rate on mortgage loans. The table below shows the model summary from the stepwise regression of the macroeconomic variables.
Table 4. Model Fitness for the various macroeconomic variables.

\begin{tabular}{lll}
\hline R Square & Adjusted R Square & Std. Error of the Estimate \\
\hline .895 & .885 & .020749 \\
\hline
\end{tabular}

This indicates that the variation in mortgage loans around its mean can to a large extent be explained by the regressor variables. Precisely, $88.5 \%$ of the variation in mortgage loans around its mean can be explained by inflation, GDP per capita, national savings rate, exchange rate, informal sector employment and formal sector employment. The stepwise regression excluded the variables exchange rate and treasury bills rate.

The table below shows the model output coefficients, $t$ test and beta statistics.

Table 5. Model coefficients, $t$ test and beta statistic.

\begin{tabular}{|c|c|c|c|c|c|}
\hline & \multicolumn{2}{|c|}{ Unstandardized Coefficients } & \multirow{2}{*}{$\begin{array}{l}\text { Standardized Coefficients } \\
\text { Beta }\end{array}$} & \multirow[b]{2}{*}{$\mathbf{t}$} & \multirow[t]{2}{*}{ Sig. } \\
\hline & B & Std. Error & & & \\
\hline (Constant) & 805.297 & 355.160 & & 2.899 & .000 \\
\hline GDP per Capita & .842 & .678 & 1.040 & 4.806 & .000 \\
\hline Inflation & .412 & 5.860 & .950 & 2.288 & .030 \\
\hline National Savings Rate & .635 & .815 & .731 & -.451 & .481 \\
\hline Exchange Rate & .065 & .489 & .629 & .094 & .608 \\
\hline Informal Sector Employment & .330 & .081 & .627 & 4.082 & .000 \\
\hline
\end{tabular}

The predictor variables were inflation, GDP per capita, national savings rate, exchange rate, informal sector employment and formal sector employment. The stepwise regression excluded the variables exchange rate and treasury bills rate.

The influence of each explanatory variable both in magnitude and direction has been estimated by the analysis. A unit increase in GDP per capita will cause a 0.842 increase in mortgage loans while a unit increase in inflation will cause a 0.412 increase in mortgage loans. A unit increase in national savings rate will cause a 0.635 increase in mortgage loans and a unit increase in exchange rate will cause a 0.065 increase in mortgage loans. A unit increase in informal sector employment causes a 0.330 increase in mortgage loans while a unit increase in formal sector employment causes 0.302 decrease in mortgage loans.

The t-statistic for each explanatory variable (i.e., the coefficient divided by the standard error) is reported in the table 4.9 above. The t-statistics for GDP per capita, informal sector employment and formal sector employment are greater than 2.462 while those for inflation and exchange rate are less than 2.462. This suggests that the regressors, GDP per capita, informal sector employment and formal sector employment are significant at the $1 \%$ level in explaining mortgage growth. Inflation, national savings rate and exchange rate are insignificant hence they add no statistically 
significant explanatory power.

At 5\% level of significance, a t-statistics for GDP per capita, inflation, informal sector employment and formal sector employment are greater than 1.699 suggests the regressors that are significant in explaining mortgage loans. In this case, national savings rate and exchange rate are insignificant.

At $10 \%$ significance level, all t-statistics are greater than 1.311 , other than national savings rate and exchange rate. This means these regressors are significant at the $10 \%$ significance level in explaining mortgage loans while national savings rate and exchange rates are statistically insignificant.

In conclusion, GDP per capita, informal sector employment and inflation have the highest influence on mortgage growth in Kenya.

\section{Conclusions}

This study finds that GDP per capita, informal sector employment and inflation have the highest influence on mortgage growth in Kenya. However, in departure from literature, inflation has a positive relationship with mortgage growth, just like GDP per capita and informal sector employment. Various cross-sectional studies such as Boamah (2009), Bryx (2006), Chiquier et al. (2004), Jaffe and Renaud (1996), Butler et al. (2009), Warnock and Warnock (2008) and Boleat (2003), Huybens and Smith (1998), Walley et al. (2013), Warnock and Warnock, (2008) and IDB (2011) among others in their cross-sectional studies argue that that the mortgage market grows in a stable macroeconomic environment. Therefore, the results suggest that in Kenya, mortgages are more driven by informal sector employment than formal sector employment. Also, Inflation in this case goes against theory and other cross-sectional studies that have established a negative influence of inflation on mortgage loans. Chiquer and Lea (2009), Merril (2006), Boamah (2009) and Warnock and Warnock (2012) that an unstable macroeconomic environment poses a high risk to the lender.

\section{References}

[1] Akinwunmi, A. (2009). An Investigation into Factors Affecting Mortgage credit Supply in Emerging Economies: A Case Study of Nigeria. PhD thesis, University of Wolverhampton.

[2] Arcelus, F. \& Meltzer, A. H. (1973b).The Markets for Housing and Housing Services: Reply. Journal of Money, Credit and Banking, 5(4): 973-978.

[3] Bandyopadhyay, A. and Saha, A. (2009).Factors driving Demand and Default Risk in Residential Housing Loans: Indian Evidence. MPRA Paper No. 14352.

[4] Beck, T., Maimbo, S. M., Faye, I., \& Triki, T. (2011). Financing Africa: through the crisis and beyond. World Bank Publications.
[5] Boamah N.A. (2009). "Secondary Mortgage Market (SMM): Is it Right for Financing Housing in Ghana?'.Journal of Science and Technology, Vol.29, No. 1.

[6] Boleat, M. (2003).Regulation of Mortgage Lending Institutions. Housing and Finance International, 18(1), 3.

[7] Butler, S., Kravova, M. \& Safavian, M. (2009). Mortgage registration and foreclosure around the globe: Evidence from 42 Countries. Mortgage credit International, June (2009), pp.19-29.

[8] CBK. (2010). Mortgage Finance in Kenya: Survey analysis.

[9] CBK. (2012). Developments in the Kenyan Banking Sector for the Quarter Ended 30th June 2012.

[10] CBK. (2013). Banking Sector Developments Report

[11] Chiquier, L., Hassler, O and Lea, M. (2004) Mortgage Securities in Emerging Markets. The World Bank.

[12] Coakes, S. J., Steed, L., and Price, J. (2008). SPSS Version 15.0 for Windows: Analysis without Anguish. John Wiley \& Sons Australia Ltd.

[13] Demir, H., Kurt, V. and Çagdas, V., (2003) "Housing Finance in Turkey" 2nd FIG Regional Conference, Marrakesh, Morrocco, 2-5 December 2003.

[14] Femi, P.J., (2013). Developing the Mortgage Sector in Nigeria through the provision of Long-term Finance: An efficiency perspective. Cranfield University, DBA Thesis

[15] Fisher, E. M. (1933). Housing Problems. The Quarterly Journal of Economics, 48(1): 129-149. The MIT Press.

[16] Gelfand, J. E. (1970). Mortgage Credit and Lower-Middle Income Housing Demand. Land Economics, 46(2): 163-170. Published by: University of Wisconsin Press.

[17] Green, R. K. and Wachter, S. M. (2005).The American Mortgage in Historical and International Context. The Journal of Economic Perspectives, 19(4): 93-114.

[18] R. Glenn Hubbard and Christopher J. Mayer (2009). The Mortgage Market Meltdown and House Prices, The B.E. Journal of Economic Analysis \& Policy: Vol. 9: Iss. 3

[19] Huybens, E. and Smith, B. (1998) Financial market frictions, monetary policy, and capital accumulation in a small open economy, Journal of Economic Theory, 81, pp. 353-400.

[20] IDB (2005) Unlocking Credit: The Quest for Deep and Stable Bank Lending. The Johns Hopkins University Press Washington, D.C.

[21] Jaffe, D. M, and Renaud, B. (1996).Strategies to develop markets in transition economies. World Bank Policy Research Working Paper 1697.

[22] Levine, R. (1997). Financial development and economic growth. Views and agenda of Economic Literature, 35 (2), 688-726.

[23] Lwali, K. (2008). Challenges of International Housing Finance Institutions; a case of Shelter Afrique. Unpublished MBA project University Of Nairobi.

[24] Mugambe, P. (2009). Access to Mortgage credit by Urban Middle-low Income Salary Earners in Kampala City, Uganda, Masters Thesis, Erasmus University. 
[25] Quigley, J. M. and Raphael, S. (2004). "Is Housing Unaffordable? Why Isn't It More Affordable?" The Journal of Economic Perspectives, 18(1); 191-214.

[26] Saleh, I. (1999) "Housing Market Dynamics in the Metropolitan Area: A Case Study of the Informal Housing Markets in the Metropolitan Jabotabek, Indonesia," University of Pennsylvania, Electronic Dissertations. http://repository.upenn.edu/dissertationsaccessed on 17th July 2014

[27] The World Bank.(2012) Financial Sector Assessment Program Development Module Mongolia Housing Finance Technical Note.
[28] Walley, S., Badev, A., Beck, T., and Vado, L. (2013) Housing Finance across Countries: New Data and Analysis. http://ssrn.com/abstract $=2336126$.accessed on 20th April 2014

[29] Warnock, V. C. \& Warnock, F. E. (2008).Markets and Housing Finance. Journal of Housing Economics, Vol. 17, No. 3, pp. 239-251. Washington, D.C.

[30] Wichura, M.J. (2006). The coordinate-free approach to linear models; Cambridge Series in Statistical and Probabilistic Mathematics. Cambridge: Cambridge University Press.

[31] Wilcox, R. (2005). Introduction to robust estimation and hypothesis testing. Academic Press. 